\title{
INVESTIGATION OF CARROT FOOD VALUE DEPENDING ON SORT PECULIARITIES AND ITS CHANGE AT STORAGE
}

\author{
Ludmila Pusik \\ Department of technologies of processing of food production ${ }^{l}$ \\ Ludmilap@gmail.com \\ Vladimir Pusik \\ Department of Agrotechnology and Ecology ${ }^{l}$ \\ kysmish@gmail.com \\ Veronika Bondarenko \\ Department of Agrotechnology and Ecology \\ zim-hot@rambler.ru \\ Ludmila Gaevaya \\ Department of fruit and vegetable and storage \\ Kharkiv National Agrarian University named after V.V. Dokuchaev \\ township Dokuchaevskoe, Kharkiv district, Kharkiv region, Ukraine, 62483 \\ Gaevaaludmila9@gmail.com \\ Natalja Kyruchina \\ Laboratory of selection of biennial and rare crops \\ Institute of Vegetable and Melon Growing \\ of National Agrarian Academy of Sciences \\ Institutska str. 1, township Selektsionnoe, Kharkiv district, Kharkiv region, Ukraine, 62478 \\ kyruchinanatalja@ukr.net \\ Halyna Slobodyanyk \\ Department of Vegetable Growing ${ }^{2}$ \\ sgy123@i.ua \\ Serhii Shchetyna \\ Department of Vegetable Growing ${ }^{2}$ \\ sv_shetina@ukr.net \\ Maryna Shchetyna \\ Department of Ecology and Life Safety ${ }^{2}$ \\ sv_shetina@ukr.net \\ Lidiia Kononenko \\ Department of Crop Production ${ }^{2}$ \\ lidakononenko123@gmail.com
}

${ }^{1}$ Kharkiv Petro Vasylenko National Technical University of Agriculture

44 Alchevskykh str., Kharkiv, Ukraine, 61000

${ }^{2}$ Uman National University of Horticulture

1 Institutska str. 1, Uman, Chercassy reg., Ukraine, 20305

Abstract

A food value of carrot roots is determined by a content of such chemical composition components as dry substance, ascorbic acid, carotene and other. The carrot value is also determined by its ability to be stored for a long time. The research aim was to study 
a food value change of different carrot sorts at storage open in boxes. The research gives an ability to search a carrot sort, suitable for long storage, and also to search arrangements for better preservation of carrot nutritiousness at storage.

It has been established, that the dynamics and intensity of losses of the roots' food value depends on sort peculiarities. Thus, during 7.5 months of storage sorts Daryna, Shantane KL and Nant Kharkiv lost from 0.92 to $4.12 \%$ of dry substance. The content of total sugar decreased by 0.16 and $0.77 \%$ of its initial content in sorts Daryna and Nant Kharkiv, whereas Shantane demonstrated the content increase at the end of storage by $0.29 \%$. The same tendency was observed also by changes of the content of monosaccharides and saccharose.

The content of ascorbic acid and carotene during storage varied from increase to decrease. At the end of storage losses of ascorbic acid and carotene were 1.43-1.93 and 3.42-4.26 mg/100 g respectively. The content of nitrates at the end of storage in Daryna roots remained at the initial level $-202 \mathrm{mg} / \mathrm{kg}$ of the humid mass, in Shantane and Nant Kharkiv it decreased by 18 and $26 \%$ respectively.

At that it must be noted, that the processes of nutritiousness changes were more intensive in Daryna and Nant Kharkiv roots. In Shantane the carrot roots content changes of chemical composition components were slower.

Keywords: carrot, sort, storage term, food value, losses, chemical composition components.

DOI: $10.21303 / 2504-5695.2020 .001588$

\section{Introduction}

Quality of vegetables is an intricate complex of parameters that determine their fitness for consumption fresh, processing or storage during a certain period without worsening of commodity and consumption properties. An assessment of fresh vegetable products is realized by outlook, consistence and also food and biological value, conditioned by the content of carbohydrates, vitamins, mineral substances [1-3].

Carrot (Daucus carota L.) is a high-nutritive root. It is used as a healing plant during near 4 thousand years. It is widely used in gastronomy as the most popular flavoring. It may also be a main product. Healthy and healing properties of carrot are explained by its rich composition. It contains vitamins of the group B, PP, C, E, K, carotene - a substance, transforming into vitamin A in the human organism. Depending on sort, carrot contains near $1.3 \%$ of proteins, $7 \%$ of carbohydrates.

Carrot contains a lot of mineral substances, necessary for the human organism: potassium, iron, phosphorus, magnesium, cobalt, copper, iodine, zinc and so on. It contains essential oils, conditioning its original smell and taste $[4,5]$.

Unfortunately, during storage carrot roots lose nutritive substances, especially contents of sugar and vitamins. Chemical changes and their intensity at storage are connected with sort peculiarities, planting and storing conditions, initial quality of roots.

The chemical composition of roots is determined by both biological peculiarities of a sort and soil-climatic and agrotechnical conditions of cultivation. The content and ratio of different substances, fraction composition and properties change under the influence of the external environment and also at all stages of organogenesis that is the chemical composition of roots is unstable and can vary widely $[6,7]$.

Numerous new sorts (136) were created, including $64 \%$ of foreign selection. 136 sorts of table carrot, including $64 \%$ of foreign selection, are registered in the State Register of sorts of Ukrainian plants [8]. Unfortunately, new sorts are assessed only by yielding capacity, ignoring food value preservation at storage. But high harvests of carrot don't solve the problem of enough population supply with high-value products in winter.

After harvesting roots continue to live at storage. Complicated enzymatic processes take place in them; the most important is breathing. It is an oxidizing process by nature and needs an oxygen inflow for its course. At breathing an organic substance oxidizes, and energy, necessary for a whole series of processes, emanates. That is the gradual loss of an organic substance for breathing processes takes place [9-11].

At the same time water evaporation by the surface takes place in stored objects. It takes place at the expanse of water diffusion from one vacuole to another, from one cell to another through semi-permeable membranes, surrounding vacuoles and the content of each cell. Water can 
also move under the influence of a hydrostatic pressure gradient through interfibrillar spaces in cellular walls [12].

It is known from literary sources [13, 14], that changes of dry substance and total sugar in vegetable products at long storage depend on intensity and directionality of breathing processes. Disintegration of an organic substance, especially carbohydrates, takes place at course of 15-20 successive reactions (Krebs cycle, Embden-Meyerhof-Parnas pathway and so on). The normal running of these chemical reactions depends on presence of a great number of enzymes, especially oxidases.

The research aim was to study a food value change of different carrot sorts at storage open in boxes.

The research gives an ability to search a carrot sort, suitable for long storage. It gives a possibility to prolong the consumption period of fresh products that has a sociological effect, and also to search arrangements for better preservation of carrot nutritiousness and decrease of its mass losses at storage. A decrease of mass losses increases the storage economic efficiency.

\section{Materials and methods for studying the intensity of carrot natural mass losses at storage}

The studies were conducted during 2017-2018 in the Institute of vegetable and melon growing of NAAS of Ukraine (Merefa city of the Kharkiv region). The institute and its experimental field are situated in the Eastern part of the Left-bank Forest-Steppe of Ukraine at the Kharkiv region territory. Carrot was cultivated using drop irrigation. At carrot cultivation, the soil humidity in the layer of $0-50 \mathrm{~cm}$ was kept by drop irrigation at level $75 \%$ of $\mathrm{NH}$.

The climate of this district is moderately continental with unstable humidification and air temperature. According to data of the metrological station of the Institute of vegetable and melon growing of NAAS, the average temperature of many years is $8.1^{\circ} \mathrm{C}$. The most cold month is January $\left(-5.5^{\circ} \mathrm{C}\right)$, the hottest - July $\left(21.3{ }^{\circ} \mathrm{C}\right)$. The average amount of precipitation is $560.2 \mathrm{~mm}$. The minimal amount of precipitation falls in March, the maximal one - in July.

The field experiments were conducted according to conventional methods [15]. They were conducted with carrot sorts Daryna, Shantane KL, Nant Kharkiv (control), included to the State Register of plant sorts, suitable for dissemination n Ukraine [8]. The sowing term is the first decade of May. The sowing method is wide-row, the scheme of plants placement: $45 \mathrm{~cm}$ - distance between rows, $5 \mathrm{~cm}$ - distance between plants in a row (Fig. 1). The plants density is 444.44 thousand units/ he. The accounting plot area is $25.6 \mathrm{~m}^{2}$, the experiment iteration is fourfold. The variants placement is systematic.

Carrot was harvested by the conventional method. Products, corresponded to the actual SSU 7035:2009, were put for storage [16]. Carrot roots were put for storage at the end of October and got out of it at the end of April. Roots were stored in a depository at temperature $0 \pm 0.5{ }^{\circ} \mathrm{C}$ and relative air humidity 85-90\%. Roots were stored according to "Methodical recommendations for storing fruits, vegetables and grape. Organization and conduction of studies" [17]. They were stored in open boxes. The mass of an average sample is $5 \mathrm{~kg}$ [18].

Observations were conducted each two months. Biochemical studies were conducted during storage by standardized methods, namely:

- content of dry substance was determined by the drying method [19];

- the total content of sugars [20]; ascorbic acid (vitamin C) [21];

- content of nitrates [22], carotene [23].

The statistical processing of obtained results was conducted using the program package «Statistica 6» and Excel.

At determining certain components of the chemical composition for comparing results at storage, the recalculation of the substances content was conducted, adjusted for a mass loss.

The characteristics of the studied sorts:

- Daryna - late ripening carrot sort, selected in Czechia near 20 years ago (Fig. 2). It is perfectly stored to the next summer. Losses of roots during a year don't exceed $8 \%$. It fits well for conservation and freezing. The vegetation period is 130-150 days from the time of continuous sprouts. The root sizes are up to $24 \mathrm{~cm}$, weight $-190-200 \mathrm{~g}$. 
- Shantane KL - late carrot sort, selected in France (Fig. 3). The vegetation period is of 130 days. Roots are of conic form with an edgeless tip, length is $10-15 \mathrm{~cm}$ and diameter is $4-6 \mathrm{~cm}$, bright orange color, mass $-300-500 \mathrm{~g}$, taste qualities are perfect. It is recommended for consumption fresh and long storage.

- Nant Kharkiv - is considered as a classic European carrot (Fig. 4). Just this sort is used as a standard by yielding capacity and roots' outlook. A Nant root is a long cylinder of middle diameter with an edgeless lower tip.

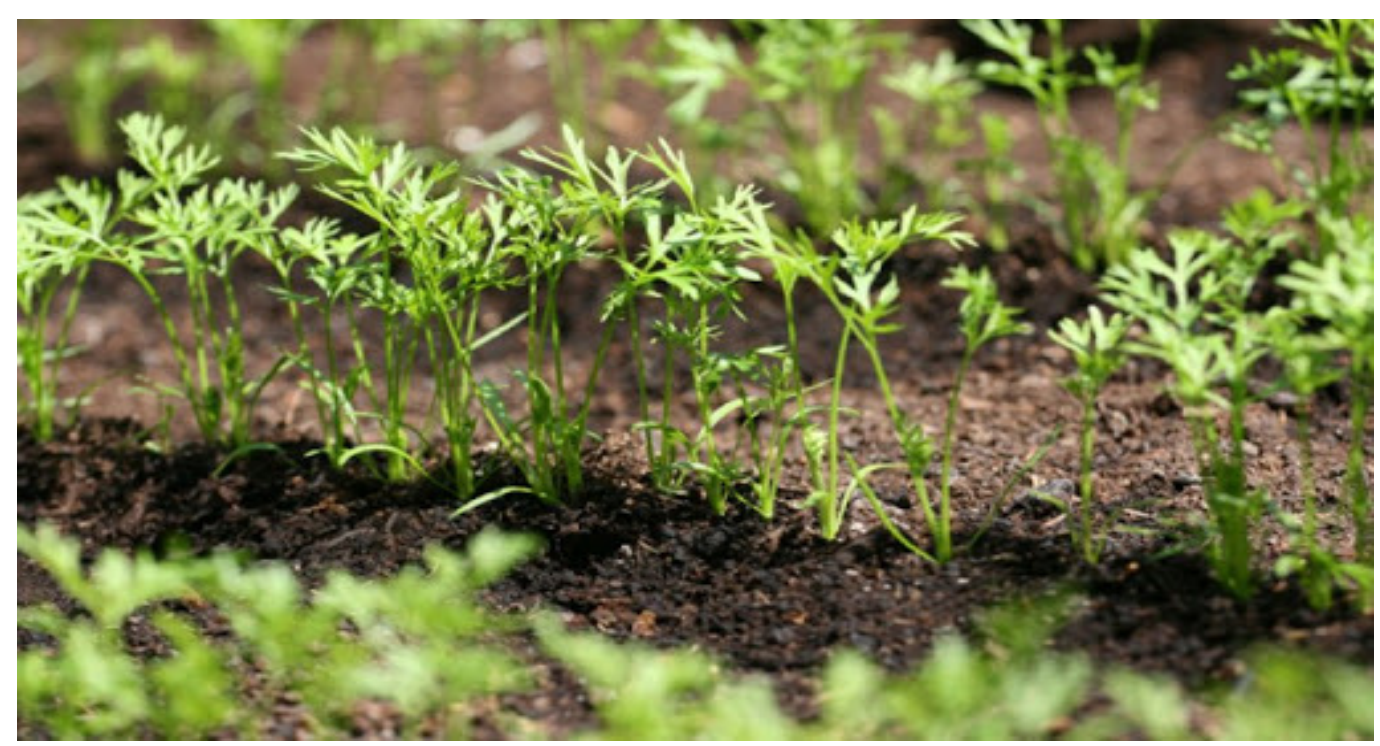

Fig. 1. Carrot sprouts

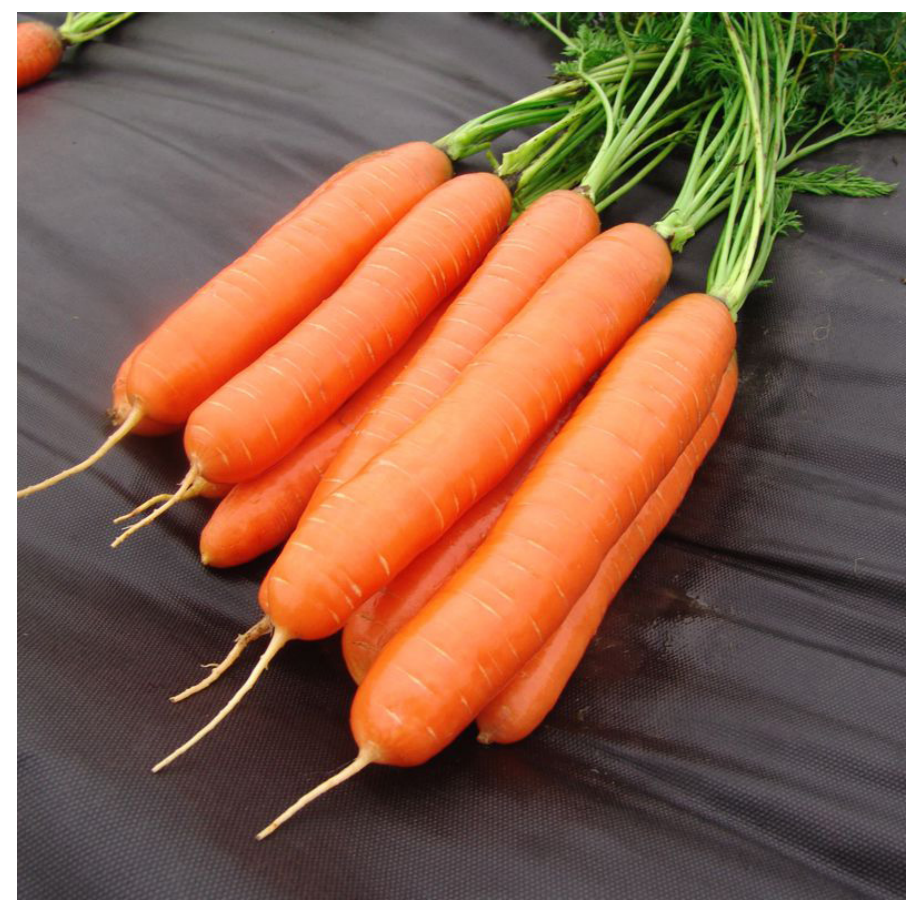

Fig. 2. Daryna

The color of this sort of roots is bright orange.

The flesh is homogenous by the whole root length. The average mass of such carrot is $80-150 \mathrm{~g}$ at the length from 11 to $16 \mathrm{~cm}$. 


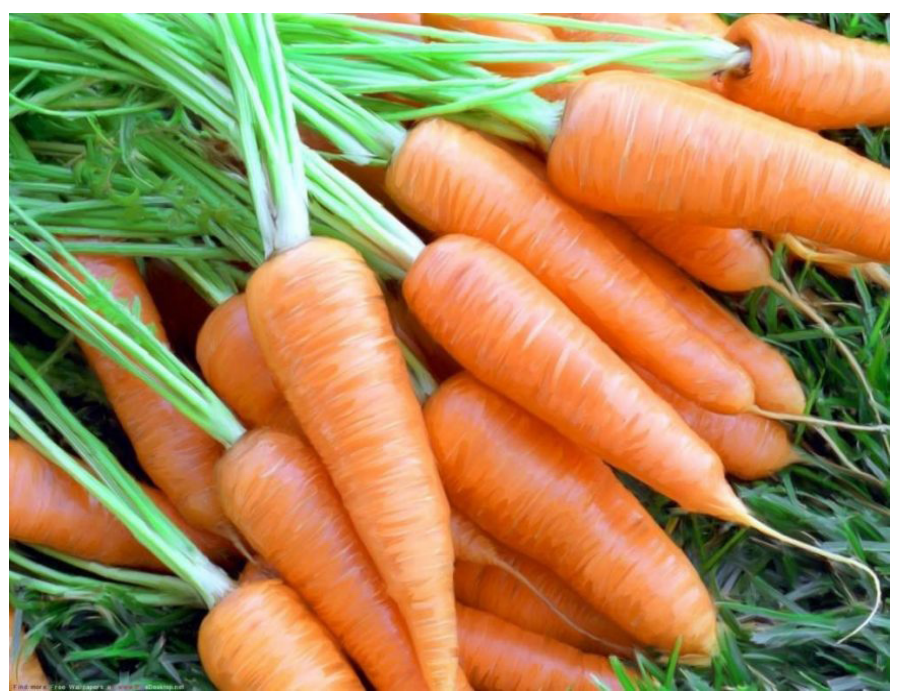

Fig. 3. Shantane KL

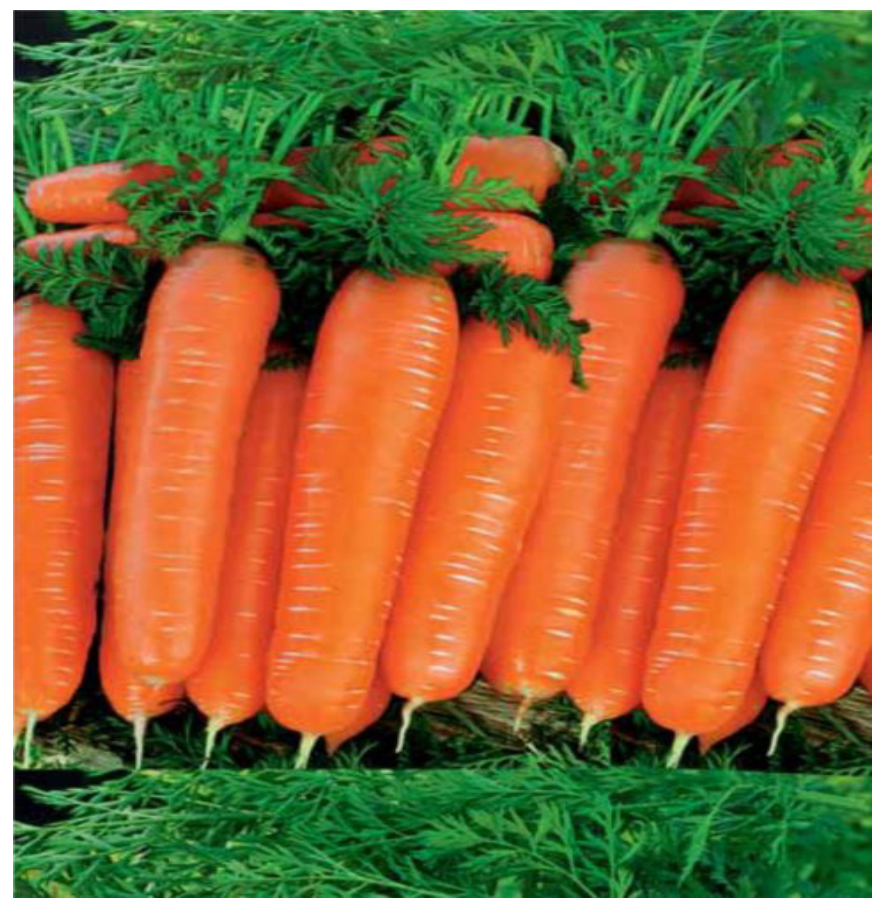

Fig. 4. Nant Kharkiv

\section{Results of the studies of food value changes of carrot at storage}

The dynamics and intensity of losses of certain carrot chemical composition components, determining its food value, has been analyzed. The tendency to gradual decrease of the dry substance content at storage in roots of the sorts Daryna (from 17.93 to $13.81 \%$ ) and Nant Kharkiv (from 16.63 to $14.41 \%$ ) has been established (Table 1). This parameter for the sort Shantane till the middle of March had been at the level of values at the beginning of storage and only afterwards decreased (from 14.28 to $13.36 \%$ ).

The content of total sugar before storage in the sorts Daryna and Nant Kharkiv was higher than in Shantane $(7.17 \%)$ as 7.84 and $8.18 \%$ respectively. But at the end of storage its content in Shantane increased by $0.29 \%$, whereas in Daryna and Nant Kharkiv - by $0.16-0.77 \%$.

The content of monosaccharides in roots of the experimental sorts Daryna (3.61\%) and Nant Kharkiv (3.68\%) a bit increases at initial storage periods and gradually decreases. At the end of storage term the content of monosugars a bit grows because of growth processes activation. The essential 
increase of the amount of monosugars from 2.98 to the level of $3.34 \%$ is observed in the first period for the sort Shantane. In further periods this index for the sort Shantane remains almost unchangeable.

Table 1

Content on certain chemical composition components in carrot roots depending on storage term (average for 2017-2018)

\begin{tabular}{ccccc}
\hline \multirow{2}{*}{ Chemical composition component } & \multirow{2}{*}{ Storage term } & \multicolumn{2}{c}{ Sort } \\
\cline { 3 - 5 } & & Daryna & Shantane & Nant Khariv \\
\hline \multirow{2}{*}{ Dry substance, $\%$} & Beginning & 17.93 & 14.28 & 16.63 \\
& End & 13.81 & 13.36 & 14.41 \\
Total sugars, $\%$ & Beginning & 7.84 & 7.17 & 8.18 \\
& End & 7.68 & 7.46 & 7.41 \\
Monosaccharides, $\%$ & Beginning & 3.61 & 2.98 & 3.68 \\
& End & 3.27 & 3.32 & 3.11 \\
Saccharose, $\%$ & Beginning & 4.02 & 3.98 & 4.18 \\
& End & 3.89 & 3.94 & 4.01 \\
Ascorbic acid, $\mathrm{mg} / 100 \mathrm{~g}$ & Beginning & 4.81 & 4.77 & 3.56 \\
Carotene, $\mathrm{mg} / \mathrm{100} \mathrm{g}$ & End & 3.11 & 3.34 & 3.63 \\
\end{tabular}

In average in the research years the content of saccharose by the sorts Daryna and Nant Kharkiv firstly increased, then decreased. At that there must be noted the sort Daryna: the increase was $1.73 \%$ of the initial content. The saccharose content decrease in roots took place gradually till the level before storage: 4.02 and $4.18 \%$ respectively. For the sort Shantane the content of saccharose during the whole storage period was almost at the same level within 3.86-4.44\%. At the end of the storage term these sorts don't essentially differ by saccharose content.

The content of ascorbic acid in carrot roots decreased in the first one and a half of the storage months: in Daryna from 4.81 to $5.15 \mathrm{mg} / 100 \mathrm{~g}$, in Nant Kharkiv from 5.56 to $5.92 \mathrm{mg} / 100 \mathrm{~g}$. Whereas in Shantane it remained unchangeable in this period as $4.8 \mathrm{mg} / 100 \mathrm{~g}$. At further storage the content of ascorbic acid in Daryna and Nant Kharkiv roots gradually decreased. In Shantane there was observed a tendency to decrease during the next four months up to $3.21 \mathrm{mg} / 100 \mathrm{~g}$. But in the two months before the storage end, its increase was fixed. So, at the end of storage the content of ascorbic acid in the sorts Daryna, Shantane and Nant Kharkiv was 3.11; 3.34 and $3.63 \mathrm{mg} / 100 \mathrm{~g}$ respectively.

Carotene is provitamin A. It transforms into vitamin A in the human organism by oxidation and hydrolysis. The sort Nant Kharkiv is characterized by the higher carotene content as $14.33 \mathrm{mg} / 100 \mathrm{~g}$. It was 12.73 and $8.73 \mathrm{mg} / 100 \mathrm{~g}$ respectively in Daryna and Shantane. Its content decreased and increased by turn each two months. And at the end of storage the carotene content in Daryna roots was $9.31 \mathrm{mg} / 100 \mathrm{~g}$, Shantane -5.24 and Nant Kharkin $-10.07 \mathrm{mg} / 100 \mathrm{~g}$. At that carotene losses are the most for the sort Nant Kharkiv as $4.26 \mathrm{mg} / 100 \mathrm{~g}$ for the whole storage period.

The content of nitrates in vegetable products is an indicator of low quality and danger for humans and animals. The maximum permissible concentration in late ripening carrot is $250 \mathrm{mg} / \mathrm{kg}$ of the wet mass. The nitrates content in roots of the experimental sorts was within 191-235 mg $/ \mathrm{kg}$ (Table 2). The most one was in the sort Nant Kharkiv, the least one - in Shantone.

Table 2

Dynamics of the nitrates content in carrot roots at storage, $\mathrm{mg} / \mathrm{kg}$ of the wet mass (average for 2017-2018)

\begin{tabular}{cccccc}
\hline Sort & $\begin{array}{c}\text { End of October (before } \\
\text { storage) }\end{array}$ & $\begin{array}{c}\text { Middle of De- } \\
\text { cember }\end{array}$ & $\begin{array}{c}\text { Middle of Feb- } \\
\text { ruary }\end{array}$ & $\begin{array}{c}\text { Middle of March } \\
\text { Middle of April } \\
\text { (after storage) }\end{array}$ \\
\hline Daryna & 200 & 241 & 232 & 249 & 202 \\
Shantane & 191 & 209 & 229 & 187 & 156 \\
Nant Kharkiv & 235 & 222 & 206 & 176 & 175
\end{tabular}


The nitrates content Daryna roots increased and decreased each two months and remained at the initial level at the end of storage: $202 \mathrm{mg} / \mathrm{kg}$. The nitrates content in the sort Shantane increased by $17 \%$ till the middle of storage. The nitrates content decreased to $156 \mathrm{mg} / \mathrm{kg}$ of the wet mass till the end of storage.

The sort Nant Kharkiv is characterized by the gradual decrease of the nitrate content during storage - to $175 \mathrm{mg} / \mathrm{kg}$ of the wet mass. The nitrates content increase in roots in initial storage periods may be connected with a decrease of cellular juice concentration as a result of moisture evaporation. At the end of the storage term, when growth processes activate in roots, a share of nitrate nitrogen transforms in ammonium forms. Such nitrogen is spent for building amino acids and protein molecules, necessary for processes of embryonic formation of new generative organs.

\section{Conclusions}

The intensity and dynamics of losses of chemical composition components, determining the food value of carrot roots, depend on sort peculiarities.

The gradual content decrease of dry substance, total sugar, saccharose and monosaccharides in roots at storage has been observed. Whereas the content of ascorbic acid, carotene and nitrates in roots at storage varied from increase to decrease. It is connected with physiological processes, taking place in roots, because carrot is a biennial plant.

\section{References}

[1] Massaglia, S., Borra, D., Peano, C., Sottile, F., Merlino, V. (2019). Consumer Preference Heterogeneity Evaluation in Fruit and Vegetable Purchasing Decisions Using the Best-Worst Approach. Foods, 8 (7), 266. doi: https://doi.org/10.3390/ foods 8070266

[2] Barrett, D. M., Beaulieu, J. C., Shewfelt, R. (2010). Color, Flavor, Texture, and Nutritional Quality of Fresh-Cut Fruits and Vegetables: Desirable Levels, Instrumental and Sensory Measurement, and the Effects of Processing. Critical Reviews in Food Science and Nutrition, 50 (5), 369-389. doi: https://doi.org/10.1080/10408391003626322

[3] Maggio, A., De Pascale, S., Paradiso, R., Barbieri, G. (2013). Quality and nutritional value of vegetables from organic and conventional farming. Scientia Horticulturae, 164, 532-539. doi: https://doi.org/10.1016/j.scienta.2013.10.005

[4] Da Silva Dias, J. C. (2014). Nutritional and Health Benefits of Carrots and Their Seed Extracts. Food and Nutrition Sciences, 05 (22), 2147-2156. doi: https://doi.org/10.4236/fns.2014.522227

[5] Matějková, J., Petříková, K. (2010). Variation in Content of Carotenoids and Vitamin C in Carrots. Notulae Scientia Biologicae, 2 (4), 88-91. doi: https://doi.org/10.15835/nsb245108

[6] Azam, A., Khan, I., Mahmood, A., Hameed, A. (2013). Yield, chemical composition and nutritional quality responses of carrot, radish and turnip to elevated atmospheric carbon dioxide. Journal of the Science of Food and Agriculture, 93 (13), $3237-3244$. doi: https://doi.org/10.1002/jsfa.6165

[7] Verma, R. S., Padalia, R. C., Chauhan, A. (2014). Chemical composition variability of essential oil during ontogenesis of Daucus carota L. subsp. sativus (Hoffm.) Arcang. Industrial Crops and Products, 52, 809-814. doi: https://doi.org/10.1016/ j.indcrop.2013.12.012

[8] State register of plant varieties suitable for dissemination in Ukraine in 2018 (2018). Kyiv, 447. Available at: https://www.sops. gov.ua/uploads/page/5aa63108e441e.pdf

[9] Larsen, H., Wold, A.-B. (2016). Effect of modified atmosphere packaging on sensory quality, chemical parameters and shelf life of carrot roots (Daucus carota L.) stored at chilled and abusive temperatures. Postharvest Biology and Technology, 114, 76-85. doi: https://doi.org/10.1016/j.postharvbio.2015.11.014

[10] Workneh, T. S., Osthoff, G., Steyn, M. S. (2011). Physiological and chemical quality of carrots subjected to pre-and postharvest treatments. African Journal of Agricultural Research, 6 (12), 2715-2724. Available at: https://academicjournals.org/article/ article1380904857_Workneh\%20and\%20Osthoff.pdf

[11] Sánchez, T., Dufour, D., Moreno, J. L., Pizarro, M., Aragón, I. J., Domínguez, M., Ceballos, H. (2013). Changes in extended shelf life of cassava roots during storage in ambient conditions. Postharvest Biology and Technology, 86, 520-528. doi: https:// doi.org/10.1016/j.postharvbio.2013.07.014

[12] Saltveit, M. E. (2019). Respiratory Metabolism. Postharvest Physiology and Biochemistry of Fruits and Vegetables, $73-91$. doi: https://doi.org/10.1016/b978-0-12-813278-4.00004-x 
[13] Adu-Kwarteng, E., Sakyi-Dawson, E. O., Ayernor, G. S., Truong, V.-D., Shih, F. F., Daigle, K. (2013). Variability of Sugars in Staple-Type Sweet Potato (Ipomoea batatas) Cultivars: The Effects of Harvest Time and Storage. International Journal of Food Properties, 17 (2), 410-420. doi: https://doi.org/10.1080/10942912.2011.642439

[14] Leroy, G., Grongnet, J. F., Mabeau, S., Corre, D. L., Baty-Julien, C. (2010). Changes in inulin and soluble sugar concentration in artichokes (Cynara scolymusL.) during storage. Journal of the Science of Food and Agriculture, 90 (7), $1203-1209$. doi: https://doi.org/10.1002/jsfa.3948

[15] Bondarenko, H. L., Yakovenko, K. I. (Eds.) (2001). Metodyka doslidnoi spravy v ovochivnytstvi i bashtannytstvi. Kharkiv: Osnova, 368.

[16] DSTU 7035:2009. Morkva svizha. Tekhnichni umovy (2010). Kyiv.

[17] Dzheneev, S. Yu. et. al.; Dzheneev, S. Yu., Ivanchenko, V. I. (Ed.) (1998). Metodicheskie rekomendatsii po hraneniyu plodov, ovoshchey i vinograda (organizatsiya i provedenie issledovaniy). Yalta: Institut vinograda i vina "Magarach", 152.

[18] DSTU:ISO 874-2002. Frukty ta ovochi svizhi. Vidbyrannia prob (2003). Kyiv.

[19] DSTU: ISO 751:2004. Produkty pereroblennia fruktiv i ovochiv. Metod vyznachannia sukhykh rechovyn, nerozchynnykh u vodi (kontrolnyi metod).

[20] DSTU 4954:2008. Produkty pereroblennia fruktiv ta ovochiv. Metody vyznachannia tsukriv (2009). Kyiv.

[21] Naichenko, V. M., Zamorska, I. L. (2010). Tekhnolohiya zberihannia i pererobky plodiv ta ovochiv. Uman: Sochinskyi, 327.

[22] DSTU 4948:2008. Frukty, ovochi ta produkty yikh pereroblennia. Metody vyznachennia vmistu nitrativ (2009).

[23] DSTU 4305:2004. Frukty, ovochi ta produkty yikh pereroblennia. Metody vyznachannia vmistu karotynu.

Received date 11.12.2020

Accepted date 14.01.2021

Published date 29.01.2021
(C) The Author(s) 2021

This is an open access article under the CC BY license (http://creativecommons.org/licenses/by/4.0). 